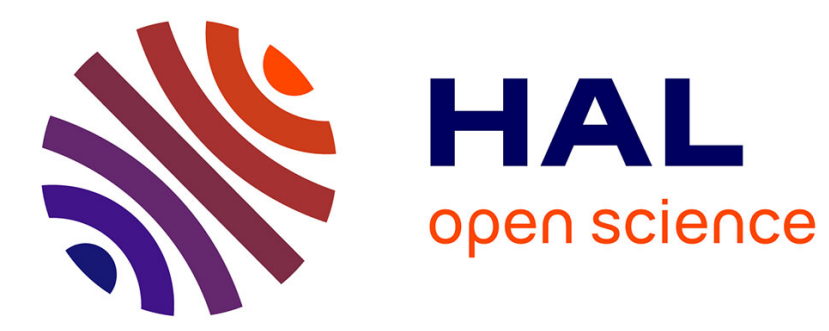

\title{
How organic farmers view their own practice: results from the Czech Republic
}

\author{
Lukas Zagata
}

\section{To cite this version:}

Lukas Zagata. How organic farmers view their own practice: results from the Czech Republic. Agriculture and Human Values, 2009, 27 (3), pp.277-290. 10.1007/s10460-009-9230-9 . hal-00510502

\section{HAL Id: hal-00510502 \\ https://hal.science/hal-00510502}

Submitted on 19 Aug 2010

HAL is a multi-disciplinary open access archive for the deposit and dissemination of scientific research documents, whether they are published or not. The documents may come from teaching and research institutions in France or abroad, or from public or private research centers.
L'archive ouverte pluridisciplinaire HAL, est destinée au dépôt et à la diffusion de documents scientifiques de niveau recherche, publiés ou non, émanant des établissements d'enseignement et de recherche français ou étrangers, des laboratoires publics ou privés. 


\title{
How organic farmers view their own practice: results from the Czech Republic
}

\section{Lukas Zagata}

Accepted: 19 March 2009

\begin{abstract}
This paper addresses the development of organic agriculture in the Czech Republic, which is seen as a success story among post-communist countries. The relatively short history of organic farming and specific contextual factors raises questions about the nature and meaning of Czech organic farming. The goal of this study was to find out how farmers view their own practice, interpret its symbolic value, and construct its content. This empirical study uses Q methodology aimed at the identification of the collectively-shared perspectives belonging engaged actors. Data were gathered through semi-standardized interviews with $\mathrm{C}$ zech farmers registered in official organic scheme. The analysis emphasized three components, which are considered as three distinct perspectives possessed by organic farmers; that is, (1) organic farming as a way of life, (2) as an occupation, and (3) as a production of food of an alternative quality compared to conventional food. Each viewpoint entails a different understanding of what organic farming means; each then - when considered together - comprises the meaning of organic agriculture in the Czech Republic. The presented classification of the farmers holding the viewpoints contributes to the ongoing theoretical discussion regarding the nature of the current organic sector, its development and potential conventionalization.
\end{abstract}

Key words Conventionalization, Czech Republic, Ecological farming, Motivation, Organic food, Organic movement, Q methodology
Abbreviations
EU European Union
IFOAM International Federation of Organic Agriculture Movements
NGO Non governmental organization 
L. Zagata (email)

Department of Humanities, Faculty of Economics and Management, Czech University of Life

Sciences Prague, Kamýcká 129, 16521 Praha 6 - Suchdol, Czech Republic

Email: zagata@pef.czu.cz

\section{Author Biography}

Lukas Zagata is Assistant Professor at the Czech University of Life Sciences, Prague. He holds master's degrees in Agricultural Economics (2003) and Sociology (2007) from the Czech University of Life Sciences - Prague, and Charles University in Prague, respectively. He earned a PhD in Regional and Social Development in 2008 from the Czech University of Life Sciences - Prague, where he also teaches. His research interest spans across sociology of agriculture, sociology of food and issues of local development.

\section{Introduction}

Organic agriculture has gained prominent position in contemporary studies of agri-food systems. It fits the new rural development paradigm (van der Ploeg et al. 2000, p. 399), functions as an important instrument in policy-making toolboxes (Dabbert et al. 2004, p. 7), and has been successful in capturing the consumer market in affluent countries (Willer et al. 2008, p. 53). However, contemporary academic studies are far from being a panegyric. Recent scholarship on the organic sector has developed a series of cautionary tales that critically reflect upon recent changes within the sector and its eventual conventionalization (Lockie et al. 2005, p. 284). The framework of this lengthy debate is well known due to the works of many authors engaged in this discussion (e.g., Coombes et al. 1998; Hall et al. 2001; Lockie et al. 2005; Tomlinson 2008). 
Generally, the organic food sector has been widely conceived as "some form of anti-dote to the concerns of society over food safety and environmental externalities" (Banks et al. 2001, p. 103) with a transformative potential to turn the modern industrialized food production into a more sustainable system. Yet in practice, organic production takes many forms and therefore the realities behind the use of this potential are open to study and discussion.

The actual research of this issue was initiated more than 10 years ago, discussed in publications of Tovey (1997) and Buck et al. (1997). These authors were the first to point out that the growing organic sector could turn out to be similar to the industrial agriculture that it has traditionally opposed, therefore undermining the intrinsic values of organic ideology. The main arguments for these theories were later elaborated as part of the conventionalization thesis, which has become a focus of other researchers in different countries, such as New Zealand (Coombes et al. 1998), Canada (Hall et al. 2001) and Germany (Best 2008). The empirical description of the conventionalization process generally refers to the concentration of capital among larger organic producers, the codification and standardization of organic practice, the erosion of organic rules, the substitution of allowable inputs, and the increasing specialization of producers (Lockie et al. 2005, p. 285-286). Nonetheless, different societal contexts do not justify the application of universal criteria which would enable us to "test" the conventionalization hypothesis in diffe rent countries.

The research project on the conventionalization of organic agriculture still goes on. Not only on the empirical level, but also in terms of the debate over the conceptualization of this subject. Some authors point out that the term conventionalization suffers from explanatory weakness, because it postulates (simplistically) a binary division of producers. Campbell et al. (2001, p. 23) argue that this situation stems from the theoretical approach of the early conventionalization works (namely by Buck et al. 1997) which appeared to excessively emphasize the commoditization, or corporatization process, which then from this viewpoint inevitably transformed small artisanal organic producers into managers of large industrial farms. The dichotomous perspective wrought by the conventionalization thesis was also criticized by Lockie et al. (2005, p. 304), who observing the tendency to bifurcate, highlighted the need to first "unpack" the concept of conventionalization, and to extend the debate over the development of organic farming. It has become clear, as Tomlinson (2008, p. 135) argues, that the series of dualisms, that apparently exist on different levels of the conventionalization process, undermine 
capacity of the thesis to inquire into the complexity of change, and the rich definitions and frames for organics, which are evolving.

This article seeks to contribute to this discussion by examining the organic sector in the Czech Republic; a contribution that should be interesting in two ways. First, by providing empirical evidence from one representative of the post-communist countries, which have thus far stayed away from this discussion; and second, by application of a theoretical and methodological framework that corresponds with a need to shift towards a more nuanced perspective on contemporary organic sectors and which overcomes the rather limited focus of the conventionalization thesis.

The aim of this study was to describe and explain the basic characteristics of the Czech organic sector. Looking at the official statistics, one can see that it has already grown from solely serving a niche market and to reaching a new - and commercial - stage of its development, similar to the pattern in Western-European countries. This situation prompts an important question: Given the unique context of organic farming in the Czech Republic, is it possible to that its particular characteristics, if adequately characterized, might enable the emerging sector to avoid the "trap" of conventionalization; and if so, how?

The discussion of the study challenges the dualistic perspective of organic farming related to the conventionalization process. The goal of the study was not to apply the conventionalization thesis, but instead to thoroughly explore and classify distinct approaches taken by organic farmers, and by doing so, demonstrate how different actors in the setting may ascribe different meanings to organics. The study considers the issue of organic farmers' motivations and values. Compared to studies conducted in other countries (Fairweather 1999; Duram 2000; Kaltoft 2001; Padel 2001; Tress 2001; Noe 2003; Darnhofer et al. 2005) this paper pays particular attention to how farmers view their own practice, how they interpret it and how they discursively construct its substance and meaning (i.e., content), since it is their reality that shapes its content as a whole.

\section{Current structure and issues of the Czech organic sector}

A brief inspection of international statistics for organic farming shows that the Czech Republic is one of the leading representatives among the post-communist countries in Central and Eastern 
Europe (Willer et al. 2008, p. 237). The number of organic farms has been growing annually as well as the share of organically farmed land, which exceeds $8 \%$ of the total land fund (MZe ČR 2009). In spite of this, there has been comparatively little effort to analyze this phenomenon and relate it to the contemporary narratives on organic agriculture. Organic farming in the Czech Republic has been mainly studied by economists, analyzing the economic performance of various sectors, such as organic beef production (Hrabalová et al. 2006); the effects of governmental subsidies (Jánský et al. 2007); environmental outcomes of organic methods (Lustigová et al. 2006) or more general trends shaping sustainable agriculture in the Czech Republic (Svatoš 2008). There have been several sociological studies conducted that have referred to the activities of Czech organic farmers (for example, Librová 2003; Lošt'ák et al. 2007), but none of these focus on the organic sector and its participants as such, or with the goal of generating information which would explain the actual form of organic agriculture in the Czech Republic. The Czech organic sector was in political terms established in the 1990s. Before the year 1989, there was no room for the organic movement in the Czech Republic (formerly Czechoslovakia) because of the overall social, political and economic conditions which mirrored the Soviet system (Lošták 1994). Establishing an organic sector was clearly inspired by thoughts of traditional organicists from abroad (see Vergner et al. 1991). Czech organic farming has been institutionalized and labeled as ecological agriculture, which is typical of the particular emphasis on ecosystem management and the biological regulation of processes (Padel 2001). This purposeful support for the concept of organic agriculture resulted in the relatively fast framework acceptance of standards from the certifying body of International Federation of Organic Agriculture Movements (IFOAM), and setting up financial support for organic farmers.

Hopeful prospects for the success of the Czech organic sector severely decreased at the end of 1992, when the new liberal government ceased economic support. According to their view, the organic sector should not have been exempted from standard market relations and therefore was disqualified from receiving extra support from public bud gets. During this period the official organic label remained unknown to the vast majority of consumers, organic food changed into a sort of "esoteric thing," and the sector as a whole stagnated (see the Figure 1). The stagnation continued until 1998, when the specific subsidy scheme for organic farmers was renewed. In the same year the national inspection and a certification agency (named KEZ) was founded. In 1999 the Act on Organic Farming (Act No. 242/2000 Coll.) was passed. This act, for the first time set 
formal rules for farmers and processors with respect to organic management and practices. Concerning the institutional framework, the Czech Republic had by that time achieved the level of the EU countries. In 2004 the government accepted the Action plan for developing Organic Farming in the Czech Republic up to 2010, which sets the goal to reach the point at which $10 \%$ of the total agricultural land in the Czech Republic would be farmed organically by 2010 (MZe ČR 2004); meanwhile the organic sector began its rapid expansion.

[Figure 1 about here]

What renders the Czech organic sector to be considered as highly developed is the increase in the number of registered farms and the relatively high share of organically farmed land (8\% in December 2008) (MZe ČR 2009), which ranks the Czech Republic among the most advanced European countries, such as Austria or Switzerland, which have a much longer organic tradition. However, if we take a look at the structure of the organic sector, we notice a significant disproportion within the amounts of organically managed land. In 2007 , more than $80 \%$ of Czech land under organic farming was held as perennial grasslands, whereas between 2001 and 2004 the share even exceeded 90\% (MZe ČR 2008). A comparison of organic enterprises with respect to their size in Europe and in the Czech Republic also shows great differences. The average size of an organic farm in Europe (EU 25) is 39 hectares, while in the Czech Republic it is more than 300 hectares (Eurostat 2007). The average size of organic farms in fact exceeds the average size of conventional Czech farms, although half of these organic farms operate on land with a size of approximately 100 ha (median value equals 109 ha).

The growing share of organically farmed land does not correspond as closely with the supplied volume of organic food in stores, which has remained at a fairly low level (Václavik 2007). Recently, large retail-chain stores (namely Tesco, Interspar, Billa, etc.) have been alerted to the market potential of organic food and the great attraction of such products. The organic label has apparently become attractive to Czech consumers, although actual purchases lag behind expectations. A representative consumer survey pointed out that only $4 \%$ of consumers buy organic products on a regular basis. The vast majority of consumers $(80 \%)$ are not able to recall any specific organic product (MZe ČR 2007). This unfavorable situation could improve following a new information campaign run by the Czech Ministry of Agriculture which seeks to 
publicly promote organic products and organic agriculture; 860,000 Euros (SZIF 2008) have been allocated for the three-year campaign.

The description above shows that the growth of the organic sector has primarily resulted from a policy "push" and only secondarily from consumer "pull" influences (see Banks et al. 2001, p. 105). The clear catalyst for making farmers consider a conversion has been financial support provided by government, rather than consumer demand or organic ideology. European organic regulation also resulted in an increasing number of organic farms and share of organically farmed land (Michelsen 2008, p. 128). This reliance on policy suggests the need for a more careful examination of the meaning of organic farming and its transformative potential.

The transformative potential, as this paper assumes, is not simply a consequence of unwitting actions of farmers. Rather, transformative potential is seen as resulting from purposeful practice framed by specific meanings of the term organic. If "organic farming defines itself as being distinct from mainstream agriculture" (Michelsen 2001, p. 10), it is important to study social institutions that maintain the differences between the organic and the conventional. The following inquiry in this paper elaborates this idea by focusing on the micro level of organic farming. It analyzes the subjective (personal) views of farmers regarding their own practice how they interpret their actions and how they make important distinctions. The aim of this paper is to provide an empirical overview of farmers' approaches to organic farming within a Czech context, and by this, the paper offers a new understanding of how a given form of organic agriculture is constructed by the participating actors.

\section{Methods}

\section{General overview}

The empirical study is based on Q methodology, originally established by the British psychologist and physicist William Stephenson (Stephenson 1953) and elaborated by his followers. The general aim of this method is to "study people's own perspectives, meanings and opinions" (Previte et al. 2007, p. 136). Current applications mostly focus on exploratory s tudies of social discourses, i.e., subjective views and attitudes of a social group towards a given 
phenomenon, issue or situation. The systematic comparison of existing perspectives then provides a look at how different actors understand the given phenomenon, what stances they take towards it, and what the situation means for them, since they are a part of the enacting of reality - in the terms of a socially constructed reality.

Q methodology may be unfamiliar because it has been overlooked within the field of social research. However, it is important to note that Q methodology has recently emerged in rural studies as a suitable research tool, which corresponds with the ongoing methodological discussions emphasizing the need of methodological pluralism (Previte et al. 2007). Detailed information, including the epistemological and methodological background of this method, can be found in the original works of founder Stephenson (Stephenson 1953) and his follower Steven Brown (1980; 1999). Condensed descriptions of the method have also been provided in the textbook of McKeown et al. (1988) and in methodological papers of Watts et al. (2005) and Previte et al. (2007). Application of the method is presented in empirically-focused publications, such as Barry et al. (2000) or Addams (2000).

Q methodology is usually carried out in six stages (Barry et al. 2000, p. 23 - 24) and is briefly presented here:

1. Researchers identify a particular discourse, which is the subject of exploration, and the relevant population.

2. The researcher conducts structured interviews with a sample of the population. A selection of statements comes from these interviews. This set of statements is usually enlarged with additional statements originating from other sources, such as newspaper or expert literature, with the goal of gathering a collection of statements that represent a relevant communication concourse that express a range of perspectives that exist for a particular area of interest. At this stage the researchers typically work with a set of $100-$ 200 statements.

3. The investigator then constructs a $Q$ sample. This refers to a selection of statements that will be shown to respondents, and form the basis for sorting and selection by respondents. The structure of the Q sample reflects a given research question. A typical Q statement set usually includes $30-60$ items (stimuli).

4. Selected individuals ( $P$ sample) are asked to evaluate and order statements on a preprepared scale, which is pyramid shaped, with placement or scores for each statement 
from the Q sample ranging from "Agree with most strongly" to "Disagree with most strongly." Q studies commonly use 9 or 13-point scales. Respondents in this way constitute individual Q sorts, which express their subjective views and attitudes. Usually a smaller number of respondents is adequate; more important than the size of the sample is the structure.

5. The researcher statistically analyzes the data, based on Q sorting by respondents, in order to reveal patterns across the participants. Q methodology is based on person-by-person correlation and factor analysis process, which is different from classical ("R") statistical analyses. The aim of the analysis is to identify a few "typical" $Q$ sorts that point out common attributes of several individual $\mathrm{Q}$ sorts.

6. These typical Q sorts are interpreted to uncover the content of shared views (i.e., discourses) with regard to the theoretical framework of the given study. Since the typical Q sort comprises several actors' views, identified discourses are not representations of any particular individuals. They rather stand for the "best-estimate," "essential," or "ideal type" account of a view that is collectively shared within each group of actors.

\section{Application of Q methodology}

Ongoing discussions about the nature of organic farming include the notion of numerous meanings of organics. Using Q methodology in this study seemed particularly apt because this research approach inherently acknowledges multiple versions of reality that are constructed by the engaged actors, and enables the researcher to uncover and describe approaches of farmers (Fairweather et. al. 2009).

Following the rules of above described methodology, I firstly focused on the exploration of the communication concourse about organic farming in the Czech Republic. For this purpose, I used three different sources: transcripts of interviews that were collected within an empirical study on Czech organic farmers during 2005-2006 (see Zagata 2007); public unofficial documents reporting about practice of organic farmers, such as the Czech social and environmental journal Sedmá generace ${ }^{1}$ and official documents provided by the Ministry of

\footnotetext{
${ }^{1}$ See http://www.sedmagenerace.cz.
} 
Agriculture, the Association of Organic Farmers and engaged civil-sector organizations (NGOs). The preliminary set included more than 100 quotations about organic farming. From these, approximately 40 were selected. Afterwards they were turned into a $Q$ sample with 36 items (statements). The construction of this $\mathrm{Q}$ sample reflected the content of the theoretical framework and research questions - to wit, approaches to organic farming and organic food production. The final selection of quotations was made on the basis of best fit with the theoretical framework, elaborated documents, and study and personal experience with organic farmers, which I had previously acquired on different occasions. The finished Q sample is listed in the Table 4.

Each quotation was written on a single card and allocated a random number (1-36). The completed "research tool" (scoring form plus the card deck) was piloted. During the actual fieldwork, I asked every person to specify his/her level of agreement to the given statements. Sorting was completed with the use of the 9-point scale showed below in Table 1. In addition, I conducted an in-depth interview with each of the farmers after they sorted their cards. The interviews asked for explanation of the way farmers sorted the cards, and finding out other important facts, which were then utilized during the interpretation phase.

[Table 1 about here]

Overall, I conducted seven interviews on various farms. The rationale of the Q methodology clearly allows the use of such small number of respondents (Previte et al. 2007, p. 139). The purpose of the sampling is not to construct a population that would enable one to generalize proportionally, but rather to explore the individual subjectivities of like-minded, and differentlyminded, actors in the setting. Thus, Q studies greatly differ in sample sizes. The rule of thumb is 30 - 40 sorters; however "highly effective Q studies can be carried out with far fewer participants" (Watts et al. 2005, p. 79). Previte et al. (Previte et al. 2007, p. 139) reported a study that used a sample of eight, Brown (Brown 1996) refers to a study that was based on six interviews.

The participants in the study were strategically sampled (Watts et al., 2005). The main priority was to purposively select actors that seemed likely to present particularly interesting perspectives in diverse contexts. To ensure that there would be different view s and attitudes with 
regard to organic farming, there were farms selected that differed in several attributes, such as: geographic location, size, business form, type and scope of production, marketing strategy etc. The basic information about the participant group is shown in Table 2; more detailed information is included in the following interpretation.

[Table 2 about here]

Every interview session resulted in one Q sort; then, all Q sorts were factor-analyzed as a data set. With regard to the percentage of explained variability, there was a three-factor solution selected (Table 3). The final solution was based on orthogonal rotation maximizing variance between loadings for each component (for more on this, see Brown 1990).

[Table 3 about here]

The individual Q sorts that constituted each factor (Factor A, Factor B, and Factor C separately) were merged together (through weighted averaging) to yield a typical Q sort. This aggregated Q sort represents the “'best-estimate' of the pattern or item configuration which characterizes that factor" (Watts et al. 2005, p. 82) i.e., the collective view of the actors within each grouping. What is commonly shared by the members of each group can be explicated with a factor score for every quotation (in a standardized form ranging from -4 to +4 ). These results are documented as factor array (Table 4) which shows item scores within each of the three typical Q sorts. Looking at the table in column form, it shows the specific configurations of the items that characterize each factor ( $\mathrm{A}, \mathrm{B}$, and $\mathrm{C})$. Reading the table in rows, it reveals the relative ranking of a particular item across all the factors.

[Table 4 about here]

\section{Perspectives on organic farming}

Organic as a way of life 
The first perspective on organic farming is extracted from the expressions of the farmers from Molehill, Cowbridge and Sheepslock (factor A). The views of the first and second farm are more closely tied together. In Molehill and Cowbridge they farm only arable land, without livestock, and both farms are of below-average size (they farm 10 and 80 ha respectively). Concerning the farm in Sheepslock, it is above-average sized farm (266 ha), and a stock company, which combines plant production with lives tock. ${ }^{2}$

It is important to take a look at the expressions (e.g., the statements themselves) which define the factor. On the right side of the scale (+4, i.e., Strongly Agree) there were the following statements:

Non-sustainability of intensive farming rests in the fact that one destroys all natural relationships with chemicals - and then must look after everything on his/her own, which is expensive. [2]

I am convinced that organic farming is a good way, which has a future. [25]

The opposite side of the scale for this factor, with score -4 indicating the lowest relative agreement, includes the statements:

Ecology must be from the smallest things and not shouted about at Temelin nuclear power station. [1]

The money from the government is basically compensation for organic farmers, who are voluntarily suppressing their production. [23].

The importance ascribed to the quotations points out the basic feature of this group, whose view is related to the traditional approach to organic farming. In particular this is in the second statement which emphasizes the holistic view of agricultural activity and nature. Conventional farming is in this sense seen as "a system that is not natural, balanced" (as was commented by a farmer in Molehill), and this is also why it is not sustainable in various ways. The recognition of this argument is additionally linked with the personal engagement and effort to influence public

\footnotetext{
${ }^{2}$ The distinctions in the approaches to organic farming have been partly diminished by the fact that the interview was conducted with the chief agronomist of the farm. His perspective on organic farming included many traditional elements, which contradicted the actual organization of their enterprise.
} 
matters with respect to the closely-held values. This fact practically means that these members are active in areas such as professional associations, the promotion of the organic sector and organic food. Their engagement is clearly based on the conviction about the positives of organic farming [25] that is linked with a certain activism. The activist element in their approach does not apply only to activities influencing specific matters around them, but also issues of a more general level [1]. This shows understanding and support for acts directed at more complex issues, such as public discussions on the use of nuclear plants. This feature is not typical of other groups (i.e., typified by Factors B and C)

According to these farmers' perspective, organic farming is not simply a political project "although the EU agrees on this, it's not like that," stated a farmer in Cowbridge - it is the result of bottom up activities. This view therefore refutes the notion that the financial support of the government could be a substitute for something that the farmers lose when they apply organic methods. The support from the public budget has a positive connotation and thus gains a form of a reward for values, which are being created and maintained by the farmers. Here again, the presented perspective overlaps with the ideas of the old organic movement.

However, the traditional approach to the organic farming of this group is not directly based on a simple counter position to contemporary life. Their view is not alternative in a narrow sense, so that the group's members would avoid ongoing events. The actors of this group succeed in the social structures of modern society, which is proven by their formal engagement in various activities. The inclination and acceptance of the traditional perspective is rather related to a higher cultural capital and a deeper understanding of organic farming origins, enriched with personal experience gained in other European countries,.

In spite of the very clear understanding of organic farming, their perspective takes into account the different meanings of organic. Respectively, acknowledging the wide context as a part of their view puts them in a somewhat ambiguous position. This fact is indicated by the score for the following statement:

Transnational retail-chain stores are a great opportunity for the development of organic farming. [18].

This stimulus was not considered as that important (factor score for this statement was -1 ), but represents the point at which the group differs from the remaining two. Supermarkets are not entirely disapproved of with regards to organic farming by the members of this group, due to 
their difficult position: a small shop in fact does not always mean "being good." Moreover, supermarkets can perform a very important role, because they offer organic food to various social groups for lower prices than small shops, etc. A more complex perspective of the first group therefore does not result in such a depreciatory judgment as occurs in the other groups.

There are three quotations that distinguish the group's perspective the most. ${ }^{3}$ They are related to the definition of organic farming [2], personal engagement [1] and the evaluation of the supermarkets' role with regard to organic farming [18]. The approach of these members is obviously founded on the traditional meanings of organic farming. Part of the original content is also the pro-active support of organic values, which are not treated in a dogmatic manner, but reevaluated with regard to current societal conditions. The partial redefinition of the original elements of organic farming is in fact their key to success.

\section{Organic farming as an occupation}

Another identified group (on factor B) represents an approach which is compounded by the perspectives recorded on Gooseage and Bullville (factor B) farms. Both farm approximately the same size of land (cca 20ha), focusing on cattle without the production of milk. They also have relatively small acreages of arable land, and Bulville farm also has an orchard. Regarding their land structure, this is the most common picture of Czech organic farming. Both farms had previously used conventional methods of farming but in the late 1990s they converted to organic agriculture. The reasons for doing so are very similar. The farm in Gooseage operates fields located in a very hilly area, where the extensive form of farming appears to be the most environmentally friendly and economic manner of production. The farm in Bullville is located in a very intensively farmed region of Central Bohemia. This farm had been gradually decreasing its production inputs, extensifying its production to the point where organic farming methods

3 Differences between groups are evaluated with the use of statistical testing of $\mathrm{z}$-score differences. The first group scored statements [1], [2] and [18] significantly differently from other two groups (1\% level of significance). 
were adopted. When the financial subsidy re-appeared in late 1990s, the farm finally decided to join the official organic scheme.

The main feature of this group's perspective is certain pragmatism towards organic farming, that is - due to many reasons - considered to be a suitable method of farming. Despite the fact that organic farming is not a direct source of the actors' social identity, as it is in the case of the first group, it is not true that organic methods would be pursued only with regard to economic reasons. Various factors, such as natural conditions, business profitability, and value orientations of farmers are so enmeshed together that it is almost impossible to identify one specific reason for farming organically.

The set of factor scores for this B group shows the statements that have become the most important within this perspective. On the positive side of the scale, there can be found:

As an organic farmer, Ifeel greatly obliged to take care of the outlook of landscape. [5]

The financial support for organic agriculture is necessary, because farming creates additional value for the whole of society, which is also noticeable on my farm. [35]

This perspective bases its interpretation of organic farming on non-productive agricultural functions. The approach is obviously closely related to the specialization of the farms, whereas illustrative members of the given group operate on perennial grasslands and breed cattle. Their production does not most likely end at a certified slaughterhouse. Due to lack of production of actual organic products, they conceive their role as maintaining the landscape [5] which they see as a legitimate reason for being supported by the public bud get [35].

The opposite side of the sort type includes the least-agreed with statements:

Personally, I do not prefer organic food or other environmentally friendly products. [24]

Transnational retail-chain stores are a great opportunity for the development of organic farming. [18]

It is interesting to see the [24] located in an extreme disagreeing position. Especially, if we compare this sorting with the previous group of traditionalists, who classified this sentence "only" with the score -2 (this implies a lesser extent of disagreement). Hence one can see that for the group of traditionalists this statement sufficiently expresses their perspective, because in their position it is already taken for granted. From this viewpoint, the group of pragmatists differs from others and rather indicates uncertainty in the construction of their social identity. Moreover, their actions belie several contradictions. One can see that these farms have been converted to 
organic, and therefore had not used organic methods since the beginning of their existence. The values of organic farming apparently were not a primary reference point for their actions, despite the fact that their ideas might have changed. Also, the production of organic food had not been the ultimate goal of their farming nor their consumption. During an interview in Gooseage, the farmer replied to my question about organic food:

I try to eat organic food! What we produce in our house, we eat! For example, potatoes and meat [...] I can't say if we would buy organic food in stores. We live here in quite a healthy way, so when we eat something bad somewhere, it's not going to hurt us. (Gooseage)

Although organic farming and its products form an important subject, which these farmers are currently dealing with, they do not occupy themselves entirely with organic issues as is the case of the first group. A much more important point that shapes their approach is the vocation of the farmer as such. This stance then includes a keen interest in the current problems of the agrarian sector, such as cheap imports of food, dissatisfaction with state policy towards farmers, or the dominant position and power of transnational corporations in relation to primary production. From this perspective statement [18] has obviously been evaluated.

The approach of this group to organic farming does not necessarily mean that it would be less valuable as it just places the emphasis on different aspects than those which earlier were identified in terms of the perspective that bound organic together with the way of life. The main distinguishing points of this group include the emphasis on non-productive functions [35], and also the emphasis on the economic limits of organic methods [20], and on the problems that entail the formalization and the control of the organic farming sector [14]. ${ }^{4}$

Farming within the organic scheme is the same as other types of farming and it must observe the basic economic parameters. [20]

A European farmer is the least free creature on Earth. [14]

It is particularly important to see how they view organic farming with regard to its historical development. What influences their stance is in fact disagreement with the statement:

\footnotetext{
${ }^{4}$ The emphasis placed on statements [35], [20] and [14] are the points in which second group differs from others (1\% level of significance).
} 
Everyone used to be an organic farmer once. [33].

Their view most likely articulates the notion that agriculture is not (even in its traditional form)

environmentally friendly per se. Organic farming is within this perspective therefore mostly considered as a formalized system, which changes the economic parameters of farming in order to produce public goods.

Organic farming as alternative production of food

Together with the two already-mentioned approaches (factors A and B), there is currently another one (factor $\mathrm{C}$ ), which has its own specifications. The content of the factor $\mathrm{C}$ discourse draws on the viewpoints that have been articulated by farmers in Horsedenbeath (approximate farm size $500 \mathrm{ha}$ ) and Ewesdoor ( $80 \mathrm{ha}$ ). Considering the relevant factor loadings, it holds that the subjective view of the farmer in Horsedenbeath is much more inclined to the described "typical perspective" than the view of the farmer in Ewesdoor. The attitude of the first farmer is (statistically) closed to Ewesdoor farm, and also to Cowbridge farm, which is a part of the group one. The position of this farm is therefore ambiguous. What turns the scale of this farm's view and resulted in placement in $\mathrm{C}$ was emphasis on the importance of organic food production.

A common denominator in this group is the accent placed on the production of organic food and the issues related to it. Horsedenbeath farm grows plants on arable land, but also farms vast perennial grasslands which are grazed by cattle and sheep. Ewesdoor farm focuses on growing various types of plants (vegetables; grain, root, and oil crops). Both farms desire to be certified organic producers. The base of the shared view is apparent with regard to the distribution of quotes, which shows the statements with the highest score:

Everyone used to be an organic farmer once. [33]

I don't like the notion of "BIO as a life-style" - a fashion for people in urban areas. [36] The statements receiving a negative evaluation:

It is not important, whether the food has a Bio (organic) label. People are more concerned about taste than anything else. [8]

Transnational retail-chain stores are a great opportunity for the development of organic farming. [18] 
Particular understandings of organic farming for $\mathrm{C}$ entail the notion of how the current organic practice is related to the past. It has already been shown from the pragmatic viewpoint (second group B) that organic farming is not seen as a renewed tradition, but rather as a formalized system that modifies the intensity of farming, which more or less retains its modernistic nature. This group's view highlights that there are localities, which are suitable for extensive farming with a focus on alternative food production, because it conveys with the natural conditions of the region and with the local farming culture [33].

This point is in fact crucial. It is the particular social construction of organic food which is seen as a part of the specific tradition in terms of its natural, rustic, and local character. This approach opposes the "urban" perspective of organic food and its popularity [36] because consumption is based on diverse reasons, and through this - from the farmers' perspective - it misses the point. Metaphorically speaking, the members of this group do not need a fancy cookbook on exotic organic food, because they are satisfied with the recipes for Old Bohemian meals made from quality ingredients, as it was in the past. Organic food meets the requirement for authenticity. Due to this, organic is still seen as an exclusive issue, which implies the need of certification and differentiation from conventional products. According to the farmers this is, after all, also important for those consumers [8] who understand these differences. The specific quality of organic products sets out distinct sales methods, which exclude supermarkets [18]. The espoused approach to organic food corresponds with the dichotomous perspective on rural/urban (or traditional/modern), whereas the higher-mentioned statements [8], [36] are the distinguishing statements of this group. ${ }^{5}$

The inclination toward the traditional perspective on organic food may even lead to the refusal of the formal $\mathrm{Czech} \mathrm{BIO}$ organic food certificate. Rural settings often enable the use of existing social networks that can be used instead of a formalized system of control and certification. Due to direct experience, people can trust the quality of produced food. They do not need the guarantees of a third party for this. Due to the absence of accredited processing companies in the Czech Republic, this situation probably concerns many organic producers. The direct sale of product in an organic quality, without the official label, challenges the point of the

\footnotetext{
5 The scores of these quotes are significantly different from the evaluation of the other two groups (1\% level of significance).
} 
entire scheme. This situation indeed highlights the formalistic character of the organic scheme. What is central to these farmers' approach is the alternative food production of a specific quality that is not necessarily based on certification.

\section{Common elements of the three perspectives}

The presented factor scores of the three "typical sorts" highlight not only the aspects which differentiate the groups, but also the elements that are common to all three perspectives. In order to complete the view on organic farming, it is useful to focus attention on these common elements well.

One of the common points of the three presented perspectives is for instance, the confidence about the function of organic farming [25]. The first group of traditionalists place more emphasis on it; however, the remaining two groups have also evaluated this item positively. This fact makes sense with regard to the various definitions employed by organic farmers. The first group conceives organic farming to be a good method, because it is consistent with their approach to nature and agriculture; for the second group, the organic method makes sense due to its agricultural-environmental potential and the formal support of the government; and finally, it satisfies the representatives of the third group because organic overlaps with traditional values and the importance of food quality.

Farmers engaged in the organic scheme also share an affiliation with values related with ecology and a "parsimonious" way of life [24]. They do not differ in this aspect, except for the pragmatists, who emphasize this point relatively more. All together they view organic farming as a broader activity, which is not limited just to food production [30]. This attitude is the most obvious in case of group A which draws on a holistic approach, although it is also present within the remaining two groups. The definition of second B group then includes the importance of the landscape, while the third group $\mathrm{C}$ relates the purpose of organic farming to the quality of food, but not necessarily certified. All groups reflect the issue of lacking organic food processing facilities. The second and third group logically share the perspective that producing non-certified products does not undermine the point of organic farming [29], which is related to their understanding of their own practice. 
Another interesting finding provides a comparison of farmers' attitudes, whether they should try to move closer to old traditions [12]. For the first and third group this quote has become so ambiguous that it ended up in an indifferent or neutral position. Only the second group graded this statement negatively. It is obvious that for them, modern technological innovations such as mechanization significantly helps in their work and they are not going to give them up. This expression vividly illustrates the content of their perspective as well as the perspectives of the other two groups.

\section{Discussion}

The central question, how farmers view contemporary organic farming, is in this study illustrated by three perspectives, expressed by three exemplifying groups of Czech farmers operating diverse farms. It is important to note that these findings do not ensure that the three perspectives are exclusive views within the Czech organic sector. Nonetheless, the presented perspectives can be treated as important yet distinct phenomena unique to the Czech Republic, whose identification and mutual comparisons contribute to the understanding of the given organic sector. Enlarging the sample of participants would increase the reliability of the factors (i.e., the sampling error of factor scores would be lower), although it is evident that even the small sample of members was able to depict basic frameworks in which the nature of "organics" is created by engaged actors.

The first perspective, named organic farming as a way of life, is founded on a holistic view on nature and agricultural practice and corresponds with traditional perspectives described by Conford (2001). This approach also includes a large concern for the phenomenon of organic farming that often promotes personal engagement at a political level, as was observed in other studies (e.g. Tovey 1997). While these types of farmers are in the minority, they should not be considered unsuccessful or unimportant. Their value orientation and other social characteristics indicate many similarities with the early adopters of organic farming in Western Europe (Padel 2001) who were clearly inspired by green ideas as the group of Ecosophists (Vartdal 1993).

The second group includes those farmers who pursue organic methods as an occupation. Their perspective points out the formal aspects of organic production. This approach is typical of 
producers whose farms that used to be conventional and were later converted to organic. Their view of organic still includes certain elements of modernistic practice, which results in two effects. Firstly, organic farming is from their perspective seen as a formalized system, which imposes restrictions on their practice. Being an organic or conventional farmer is then judged with respect to the costs of administration, control, and received subsidies. Secondly, the actors' understanding and actual practice include many contradictions. They have no doubts about being organic farmers, but their practice is not as consistent as in the case of the first group. They are the Vartdal's reformists (Vartdal 1993), who converted after the scheme became more accessible to "normal" farmers and started to be subsidized by the government.

The third group, organic farming as an alternative food production, stems from a particularly Czech context. The meaning of organic farming corresponds with the traditional methods of food production in certain regions and in this way it offers a potential alternative to industrial production. The formality of the official organic scheme, particularly the strict rules on processing food in an organic way, cause these farmers forfeit official labels. This situation is enabled and indeed intensified by various contextual factors, such as the lack of accredited organic food processing facilities, undeveloped local markets, and inaccessible distribution channels to remote markets in large cities. This group's approach to organic has the obvious potential to animate certain aspects of rural culture and through this establish new forms of cooperation between the rural and urban population in terms of rural development, as in Austria (Darnhofer 2005). However, the current failure of the production and processing sector of organic food is, for them, challenging the purpose of the official scheme.

Each farmer considers themselves to be organic/ecological, whereas the specific forms of their approaches greatly vary. In particular there is an interesting approach of the second group, the less-committed, pragmatically oriented farmers. The analysis shows that these are converted conventional farms with a specific approach to organic farming. As Best (2008) correctly asserted, this does not necessarily make them be the enterprises that are producing organic as they would produce any other commodity, in order to meet the suggested criteria of conventionalization. The approach of the Czech pragmatists included many contradictory features, but overall being organic was an important part of the investigated farmers' personal views. This evidence challenges the notion that this group of farmers is inevitably 
conventionalizing the organic sector, since their value orientation does not lack a potential for strengthening organic activities and also increasing the consistency of their stances.

\section{Conclusions}

Farmers participating in organic practice and programs are operating under specific motives, which are in various ways derived from organic ideology, in spite of the absence of this tradition of farming in the Czech Republic. Moreover, the constructivist approach shows that organic farming takes different forms from the farmers' perspectives and views, resulting in different styles of organic farming. In the introduction it was argued that the dualistic classification of organic farmers is not suitable for examining the current organic sectors. The study suggests that farmers view and realize the organic practice in different ways, which result in more than two statistically-relevant definitions of the organic (cf. committed vs. pragmatic). Additionaly, the study shows that the differences between the approaches of the farmers may not be as dramatic as they might seem. It is obvious that the committed "idealists," in order to survive on the market, must act in a certain manner pragmatically. Similarly, the "pragmatists" absorb a part of the enthusiasm for organic farming and ideas that are typical of the idealists. This fact is supported by the description of common elements within the groups' perspectives, showing how the organic farmers' activities are tailored to a specific social setting. In terms of a formalized scheme of organic agriculture, the setting is delineated by elements of contemporary market society on one side and idealized symbolic meanings of organic on the other side. This situation results in specific strategies (adopted by each group) which are intended to balance the normative requirements of market institutions and, at the same time, to preserve the symbolic value of the exerted practice in relation to their social environment (e.g., the lay public).

The achievements of each group are then determined by their strategies, which underlies a specific farming style (van der Ploeg 1994). Each strategy ensures a specific unity of thinking and doing with regard to how farming should be done in order to keep the desired identity, and to adjust to structural conditions and succeed on market. The success of the group of traditionalists is based on the partial modification of the original values. This strategy therefore emphasizes the oncoming professionalisation rather than the conventionalization of organic practice, as 
suggested by Darhnofer (2006). The second group - pragmatists - demonstrates that they have voluntarily limited certain modernistic elements within their actions, in order to become and to be considered as organic farmers. The potential modification of their approach does not allow them to view their contribution negatively. The strategy of the third group - the organic food producers - oscillates between informal and formal procedures centered on the notion of guaranteeing the quality of their products.

The development of the organic sector, and its desired outcomes, is indeed limited by the above-mentioned framework, in which the farmers assuredly act. Based on empirical evidence, I wish to argue that these acts and their outcomes cannot be reduced to binary categories in terms of a conventionalization thesis. The question whether organic farming is able to provide a bona fide alternative to conventional agriculture seems to be related to the nature of the principal institutional forms of the setting in which the organic practice takes place. Recognizing this fact adds a new aspect to the ongoing debate on conventionalization.

\section{Acknowledgme nts}

The author would like to acknowledge the helpful comments from the editor and two anonymous referees for their inspirational remarks. Many thanks also go to the farmers, who took part in the research. This paper was supported by the grant "Economics of resources of Czech agriculture and their efficient use in the framework of multifunctional agri-food systems" funded by the Czech Ministry of Education (Grant No. 6046070906).

\section{References}

Act No. 242/200 Coll. On organic farming.

Addams, H. 2000. Q Methodology. In Social discourse and environmental policy: an application of $Q$ methodology, ed. H. Addams and J. Proops, 14-40. Glos, UK: Edward Elgar Publishing. 
Banks, J., and T. Marsden. 2001. The nature of rural development: the organic potential. Journal of Environmental Policy \& Planning 3(2): 103-121.

Barry, J., and J. Proops. 2000. Citizenship, sustainability and environmental research: $Q$ methodology and local exchange trading systems. Glos, UK: Edward Elgar Publishing.

Best, H. 2008. Organic agriculture and the conventionalization hypothesis: A case study from West Germany. Agriculture and Human Values 25(1): 95-106.

Brown, S. R. 1980. Political subjectivity: Application of Q Methodology in Political Science. New Haven, USA: Yale University Press.

Brown, S. R. 1996. Q methodology and qualitative research. Qualitative Health Research 6(4): 561-567.

Brown, S. R. 1999. Q methodology. In Handbook of research methods in public administration, ed. G. J. Miller and M. L. Whicker, 599-637. New York, NY: Marcel Dekker.

Buck, D., C. Getz, and J. Guthman. 1997. From farm to table: the organic vegetable commodity chain of Northern California. Sociologia Ruralis 37(1): 3-21.

Campbell, H., and R. Liepins. 2001. Naming organics: understanding organic standards in New Zealand as a discursive field. Sociologia Ruralis 41(1):21-39.

Conford, P. 2001. The origins of the organic movement. Edinburgh, UK: Floris Books.

Coombes, B., and H. Campbell. 1998. Dependent reproduction of alternative modes of agriculture: organic farming in New Zealand. Sociologia Ruralis 38(2): 127-145.

Dabbert, S., A. N. Häring, and R. Zanoli. 2004. Organic farming: policies and prospects. UK: Zedbooks.

Darnhofer, I. 2005. Organic farming and rural development: some evidence from Austria. Sociologia Ruralis 45(4): 308-323.

Darnhofer, I., W. Schneeberger, and B. Freyer. 2005. Converting or not converting to organic farming in Austria: farmer types and their rationale. Agriculture and Human Values 22(1): 39-52.

Darnofer, I. 1996. Organic farming between professionalisation and conventionalisation - The need for a more discerning view of farmer practices. http://orgprints.org/7390/. Accessed 7 January 2009.

Duram, L. A. 2000. Agents' perception of structure: How Illinois organic farmers view po litical, social and ecological factors. Agriculture and Human Values 17(1): 35-48. 
Eurostat. 2007. Eurostat news release 80/2007 - 12 June 2007.

Fairweather, J. R. 1999. Understanding how farmers choose between organic and conventional production: results from New Zealand and policy implications. Agriculture and Human Values 16(1): 51-63.

Fairweather, J. R., and K. Klonsky. 2009. Response to Vanclay et al. on farming styles: Q methodology for identifying styles and its relevance to extension. Sociologia Ruralis 49(2): 189-198.

Hall, A., and V. Mogyorody. 2001. Organic farmers in Ontario: an examination of the conventionalization argument. Sociologia Ruralis 41(4): 399-422.

Hrabalová, A., and K. Zander. 2006. Organic beef farming in the Czech Republic: structure, development and economic performance. Agricultural Economics - Zemědělská ekonomika 52(2): 89-100.

Jánský, J., and I. Živělová. 2007. Subsidies for the organic agriculture. Agricultural Economics Zemédělská ekonomika 53(9): 392-402.

Kaltoft, P. 2001. Organic farming in late modernity: at the frontier of modernity or opposing modernity? Sociologia Ruralis 41(1): 146-158.

Librová, H. 2003. Vlažní a váhaví. Kapitoly o ekologickém luxusu. Brno, Czech Republic: Doplněk.

Lockie, S., and D. Halpin. 2005. The 'conventionalisation' thesis reconsidered: structural and ideological transformation of Australian organic agriculture. Sociologia Ruralis 45(4): 284-307.

Lošt’ák, M. 1994. From socialist equality to post-socialist diversity? (The case of local initiatives and their role in the Czech countryside). Agricultural Economics - Zemédélská ekonomika 40(11): 893-906.

Lošt’ák, M., and E. Kučerová. 2007. The impacts of local endogenous initiatives on the public (the case of the Tradice Bílých Karpat). Agricultural Economics - Zemédělská ekonomika 53(11): 495-504.

Lustigová, L., and P. Kušková. 2006. Ecological footprint in the organic farming system. Agricultural Economics - Zemědělská ekonomika 52(11): 503-509.

McKeown, B., and D. Thomas. 1988. Q methodology. Sage University Paper Series on Quantitative Application in the Social Sciences, No. 66. London, UK: Sage. 
Michelsen, J. 2001. Recent development and political acceptance of organic farming in Europe. Sociologia Ruralis 41(1): 3-20.

Michelsen, J. 2008. A Europeanization deficit? The impact of EU organic a griculture regulations on new member states. Journal of European Public Policy 15(1): 117-134.

MZe ČR. 2004. Action plan for developing organic farming in the Czech Republic to the year 2010. Prague, Czech Republic: Ministry of Agriculture of the Czech Republic.

MZe ČR. 2007. Biopotraviny - ano, ale co to je?/Organic food-yes, but what is it? Ministry of Agriculture of the Czech Republic. http://81.0.228.70/attachments/GFK-BIO_zari07.pdf. Accessed 7 July 72008.

MZe ČR. 2008. Yearbook 2008 - Organic farming in the Czech Republic. Ministry of Agriculture of the Czech Republic. Prague, Czech Republic: Ministry of Agriculture of the Czech Republic. http://www.mze.cz/attachments/rocenka_v_Aj_08-na_web.pdf. Accessed 7 January 2009.

MZe ČR. 2009. Základní statistické údaje ekologického zemédélství k 31.12.2008/Basic statistical facts about organic farming 31.12.2008. Prague, Czech Republic: Ministry of Agriculture of the Czech Republic. http://www.mze.cz/Index.aspx?ch=73\&typ=1\&val=43540\&ids=0\&katId=3343. Accessed 13 March 2009.

Noe, E. 2003. The paradox for the diffusion of organic farming in Denmark. In Sociological perspectives of organic agriculture: from pioneer to policy, ed. G. Holt and M. Reed, 210226. Wallingford, UK: CABI.

Padel, S. 2001. Conversion to organic farming: a typical example of the diffusion of an innovation? Sociologia Ruralis 41(1): 40-61.

Previte, J., B. Pini, and F. Haslam-McKenzie. 2007. Q methodology and rural research. Sociologia Ruralis 47(2):135-147.

Stephenson, W. 1953. The study of behavior. Q-technique and its methodology. Chicago, IL: The University of Chicago Press.

Svatoš, M. 2008. Selected trends forming European agriculture. Agricultural Economics Zemědělská ekonomika 54(3): 93-101.

SZIF. 2008. Nová kampaň na podporu bio výrobků/New camping promoting organic products. The State Agricultural Intervention Fund. 
http://www.jimebio.cz/index.php?section=spotrebitel\&page=bio_kampan. Accessed 7 July 2008.

Tomlinson, I. 2008. Re-thinking the transformation of organics: the role of the UK government in shaping British organic food and farming. Sociologia Ruralis 48(2): 133-151.

Tovey, H. 1997. Food, environmentalism and rural sociology: On the organic farming movement in Ireland. Sociologia Ruralis 37(1): 21-37.

Tress, B. 2001. Converting to organic agriculture - Danish farmers' views and motivations. Geografisk Tidsskrift 101(1): 131-143.

Václavík, T. 2007. Český trh s biopotravinami. Greenmarketing, Moravské Knínice, Czech Republic: Greenmarketing.

van der Ploeg, J.D., et al. 2000. Rural development: from practices and policies towards theory. Sociologia Ruralis 40(4): 391-408.

van der Ploeg, J.D. 1994. Styles of farming: an introductory note on concepts and metodology. In Endogenous regional development in Europe, ed. H.J. de Haan and J.D. van der Ploeg, 731. Luxembourg.

Vartdal, B. 1993. Motivatsjon og meistring av omlegging til oekologisk jordbru. Trondheim, Norway: Sentre for Bygedforskning and Norsoek.

Vergner, I., and R. J. Barták. 1991. Základy alternativního zemédělství. Prague, Czech Republic: Ministry of Agriculture of the Czech Republic.

Watts, S., and Stenner, P. 2005. Doing Q methodology: theory, method and interpretation. Qualitative Research in Psychology 1(2): 67-91.

Willer, H., M. Yussefi-Menzler, and N. Sorensen. 2008. The world of organic agriculture Statistics and emerging trends 2008. http://orgprints.org/13123/. Accessed 7 July 2008.

Zagata, L. 2007. Bio cash-cow? Context and content of Czech organic farming. Agricultural Economics - Zemědělská ekonomika 53(1): 45-53. 
Table 1. Q sort score sheet $(\mathrm{N}=36$ statement items).

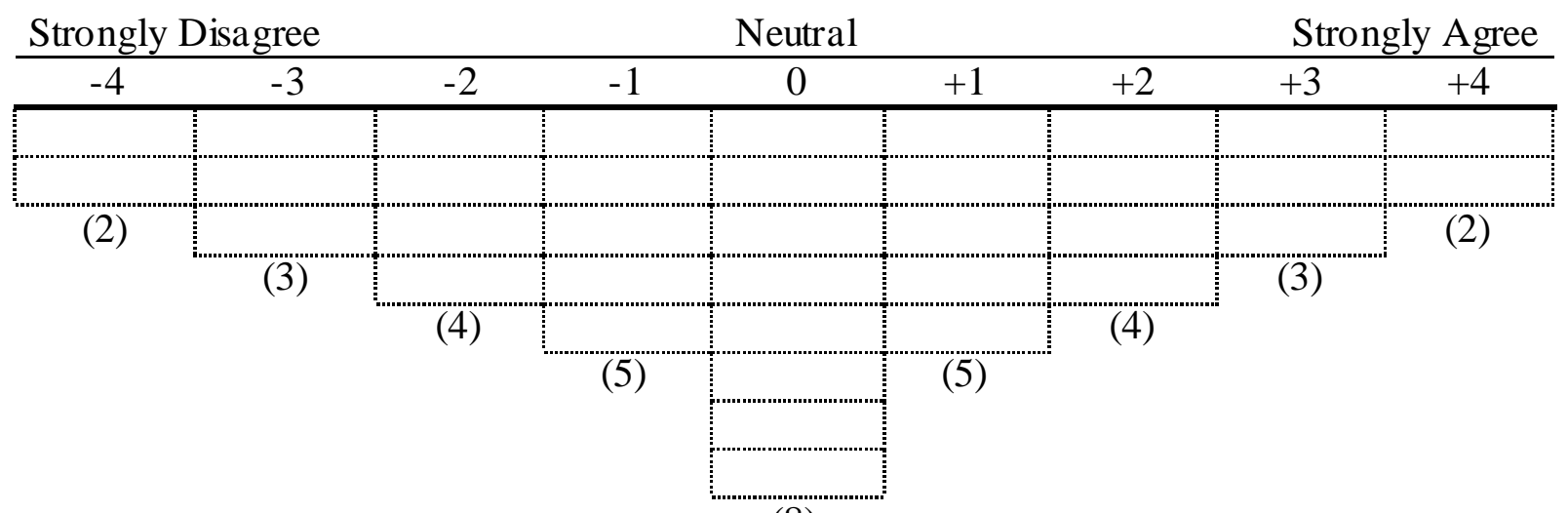

(8)

Table 2. Overview of the participating farms and their basic characteristics.

\begin{tabular}{lllll}
\hline Farm* & District & $\begin{array}{l}\text { Approximate } \\
\text { size (ha) }\end{array}$ & $\begin{array}{l}\text { Livestock } \\
\text { (Y/N) }\end{array}$ & Business form \\
\hline Bullville & Kladno & 20 ha & Y & Natural person \\
Gooseage & Tabor & 25 ha & Y & Natural person \\
Molehill & Litomerice & 10 ha & N & Corporate body \\
Ewesdoor & Litomerice & 75 ha & N & Natural person \\
Cowbridge & Beroun & 88 ha & N & Corporate body \\
Sheepslock & Prague - East & 266 ha & Y & Corporate body \\
Horsedenbeath & Uherske Hradiste & 500 ha & Y & Corporate body \\
\hline
\end{tabular}

* In order to maintain the anonymity of the farmers, the names of the localities have been changed.

Table 3. Factor loading of the final solution - three components after rotation.

\begin{tabular}{l|ccc}
\hline & A & B & C \\
\hline 3. Molehill & 0,92 & 0,01 & 0,09 \\
5. Cowbridge & 0,69 & 0,20 & 0,39 \\
6. Sheepslock & 0,63 & 0,46 & 0,00 \\
2. Gooseage & 0,00 & 0,84 & 0,22 \\
1. Bulville & 0,48 & 0,70 & $-0,08$ \\
7. Horsedenbeath & 0,03 & $-0,02$ & 0,93 \\
4. Ewesdoor & 0,35 & 0,42 & 0,68 \\
\hline
\end{tabular}

Note: Extraction method was principal components analysis (PCA); Rotation method used Varimax with Kaiser normalization. 
Table 4. Factor scores of statements of three groups (scores of Q-set).

\begin{tabular}{|c|c|c|c|c|}
\hline \multicolumn{2}{|c|}{ Quotation number and text } & \multirow{2}{*}{ A } & \multirow{2}{*}{$\begin{array}{l}\mathrm{B} \\
+2\end{array}$} & \multirow{2}{*}{$\begin{array}{l}\mathrm{C} \\
+1\end{array}$} \\
\hline 1 & $\begin{array}{l}\text { Ecology must be from the smallest things and not shouted about at } \\
\text { Temelin nuclear power station. }\end{array}$ & & & \\
\hline 2 & $\begin{array}{l}\text { Non-sustainability of intensive farming rests in the fact that one } \\
\text { destroys all natural relationships with chemicals - and then must } \\
\text { look after everything on his/her own, which is expensive. }\end{array}$ & +4 & 0 & 0 \\
\hline 3 & $\begin{array}{l}\text { Organic farm animals do not necessarily live better than those on } \\
\text { conventional farms. It's a matter of how individual people treat } \\
\text { them. }\end{array}$ & 0 & +2 & +1 \\
\hline 4 & $\begin{array}{l}\text { As an organic farmer, I am not pleased that vegetables are } \\
\text { imported from abroad, but it is needed. }\end{array}$ & 0 & 0 & -2 \\
\hline 5 & $\begin{array}{l}\text { As an organic farmer, I feel greatly obliged to take care of the } \\
\text { outlook of landscape. }\end{array}$ & +3 & +4 & 0 \\
\hline 6 & $\begin{array}{l}\text { An environmentally friendly approach is a matter of course for me } \\
\text { and whenever I have opportunity, I try to implement it in practice. }\end{array}$ & +2 & +2 & 0 \\
\hline 7 & The most beautiful thing is to see that the animals are well.' & +2 & 0 & -2 \\
\hline 8 & $\begin{array}{l}\text { It is not important, whether the food has a Bio (organic) label.' } \\
\text { People are more concerned about taste than anything else. }\end{array}$ & 0 & -1 & -4 \\
\hline 9 & $\begin{array}{l}\text { In the case of conventional food, customers are paying only part of } \\
\text { the price; the remainder is subsidized by the state from its public } \\
\text { health-care program. }\end{array}$ & +2 & 0 & -2 \\
\hline 10 & $\begin{array}{l}\text { I sell my products to those who offer the highest price and for this, } \\
\text { there is no organic certificate required. }\end{array}$ & -1 & -1 & -1 \\
\hline 11 & $\begin{array}{l}\text { We are paid by the state and so we have to farm in accordance with } \\
\text { its policy on subsidies. }\end{array}$ & -1 & 0 & +1 \\
\hline 12 & I think that organic farmers should draw on old traditions. & 0 & -2 & 0 \\
\hline 13 & $\begin{array}{l}\text { Organic food is always more expensive, but when the goods have } \\
\text { perfect quality, the price is not that important. }\end{array}$ & +1 & 0 & -1 \\
\hline 14 & A European farmer is the least free creature on Earth. & -3 & +2 & -2 \\
\hline 15 & $\begin{array}{l}\text { Conventional food can only be bought with the awareness that it is } \\
\text { not as healthy as organic food. }\end{array}$ & +1 & -1 & -3 \\
\hline 16 & $\begin{array}{l}\text { Farmers used to be self-reliant and were driven by common sense. } \\
\text { Nowadays, they do not rely on experts, but bureaucrats. }\end{array}$ & +1 & +1 & +3 \\
\hline 17 & $\begin{array}{l}\text { Organic farming is a political project focused on the problem of } \\
\text { food surplus. }\end{array}$ & -3 & -3 & +1 \\
\hline 18 & $\begin{array}{l}\text { Transnational retail-chain stores are a great opportunity for the } \\
\text { development of organic farming. }\end{array}$ & -1 & -4 & -4 \\
\hline 19 & $\begin{array}{l}\text { Subsidies are only supposed to discipline farmers. I would be } \\
\text { happier if there were no subsidies. }\end{array}$ & -1 & +1 & +3 \\
\hline 20 & $\begin{array}{l}\text { Farming within the organic scheme is the same as other types of } \\
\text { farming and it must observe the basic economic parameters. }\end{array}$ & -1 & +3 & -1 \\
\hline 21 & $\begin{array}{l}\text { Organic farming does not necessarily imply lower product. It is } \\
\text { rather less reliable. }\end{array}$ & +1 & -1 & +2 \\
\hline
\end{tabular}




\begin{tabular}{|c|c|c|c|c|}
\hline 22 & $\begin{array}{l}\text { Organic farming should offer all kinds of food including meat. It } \\
\text { should not be limited to "grain" and "vegetarian food". }\end{array}$ & +3 & 0 & +3 \\
\hline 23 & $\begin{array}{l}\text { The money from the government is basically compensation for } \\
\text { organic farmers, who are voluntarily suppressing their production. }\end{array}$ & -4 & -3 & 2 \\
\hline 24 & $\begin{array}{l}\text { Personally, I do not prefer organic food or other environmentally } \\
\text { friendly products. }\end{array}$ & -2 & -4 & -3 \\
\hline 25 & $\begin{array}{l}\text { I am convinced that organic farming is a good way, which has a } \\
\text { future. }\end{array}$ & +4 & +3 & +2 \\
\hline 26 & $\begin{array}{l}\text { Subsidies should only be received by real farmers, those who } \\
\text { produce BIO (organic). }\end{array}$ & 0 & -2 & 0 \\
\hline 27 & $\begin{array}{l}\text { In organic farming there are many vegetarians with addled heads, } \\
\text { who think that organic means eating only (wheat) flakes and } \\
\text { grains. }\end{array}$ & -2 & -2 & 0 \\
\hline 28 & $\begin{array}{l}\text { The traditional way of farming, which was largely based on } \\
\text { manual work, does not make me happy. }\end{array}$ & -2 & 0 & +1 \\
\hline 29 & $\begin{array}{l}\text { If an organic farmer sells his/her product without certification, then } \\
\text { organic farming loses its point. }\end{array}$ & 0 & -3 & -1 \\
\hline 30 & Organic farming is more than just not-using chemical substances. & +3 & +2 & +2 \\
\hline 31 & $\begin{array}{l}\text { Organic farmers should also eat organic food; otherwise organic } \\
\text { farming loses a part of its point. }\end{array}$ & 0 & 0 & 0 \\
\hline 32 & $\begin{array}{l}\text { There are only a few people, who eat BIO and this will hardly ever } \\
\text { change. }\end{array}$ & -3 & +1 & -3 \\
\hline 33 & Everyone used to be an organic farmer once. & +2 & -2 & +4 \\
\hline 34 & $\begin{array}{l}\text { The production of certified food is the principal purpose of organic } \\
\text { farming. }\end{array}$ & 0 & +1 & -1 \\
\hline 35 & $\begin{array}{l}\text { The financial support for organic agriculture is necessary, because } \\
\text { farming creates additional value for the whole of society, which is } \\
\text { also noticeable on my farm. }\end{array}$ & +1 & +4 & 0 \\
\hline 36 & $\begin{array}{l}\text { I don't like the notion of "BIO as a life-style" - a fashion for } \\
\text { people in urban areas. }\end{array}$ & -2 & +1 & -4 \\
\hline
\end{tabular}

Note: Statements translated from original Czech into English by author. 
Figure 1. Number of organic farms and relative share of organic land in the Czech Republic in the years $1990-2008$.

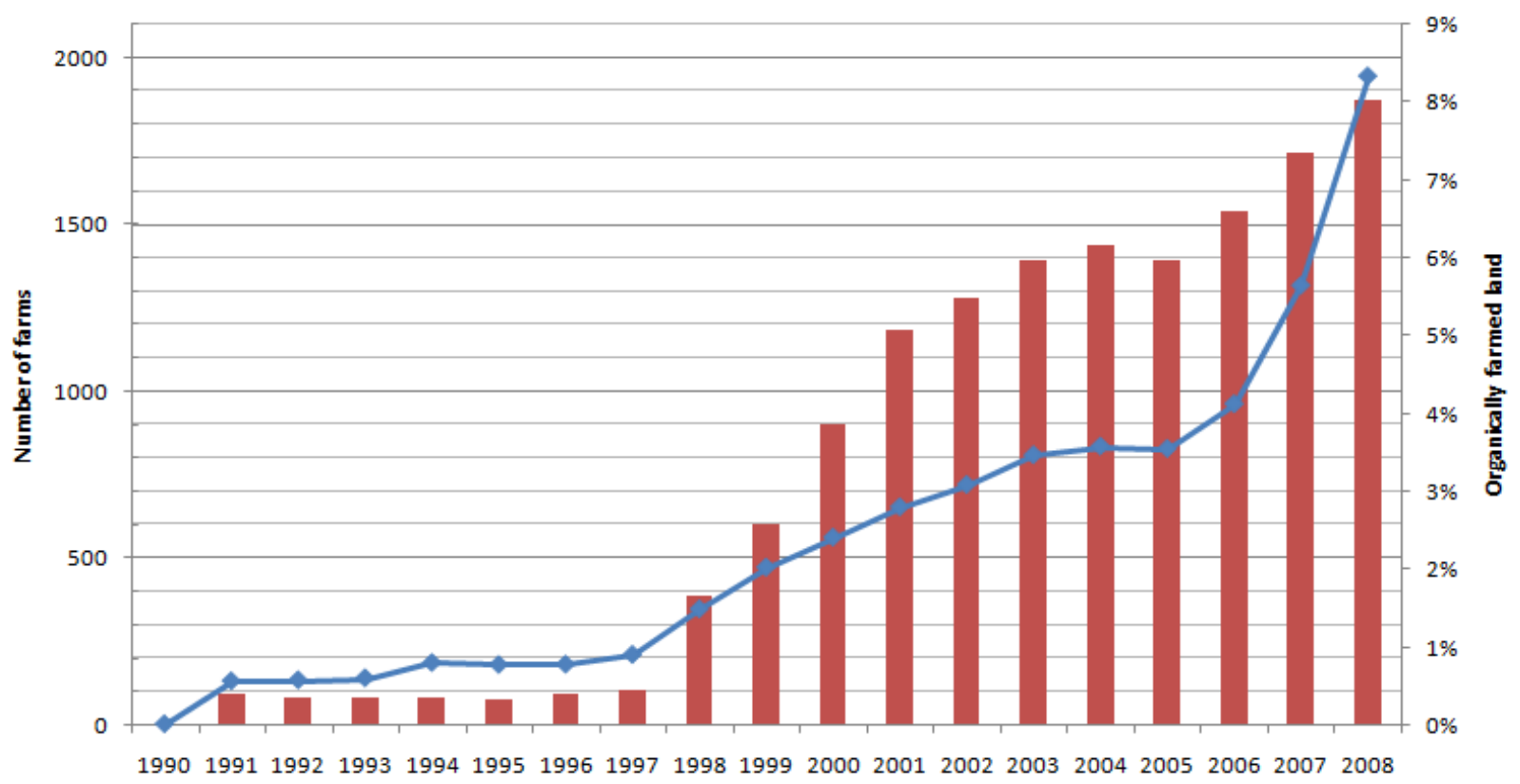

Source: MZe ČR (2009 